Not merely in the lower, but also in the higher forms of animal life the microscopist is constantly encountering anomalous appearances, structures, "bodies," \&c. ; some of these developments being regarded as normal, whilst others are relegated to the category of pathological products. In very many cases the mysterious organisms in question have been described as "glands;" the variable character of this system of structures affording a convenient refuge for the destitute. More astute observers, however, refuse to adopt such subterfuges, and have accordingly been satisfied either merely to note their characters without forming any definite conclusions, or they have gone only a step further by placing them within the territory of superfluous developments.

To take a few familiar instances occurring within the domain of helminthology. We have the so-called Raineyan sacs, regarded as the earliest stages of Cysticerci by their discoverer. Similar bodies were previously described as the products of muscular degeneration by Hessling. Finally, they were pronounced by Leuckart to be psorosperms. In the year 1856 I detected granular bodies in the early stage of development of the eggs of Tania, respecting the nature of which I had then no means of forming any definite opinion. These were subsequently described by Weinland and Leuckart; the latter authority looking upon them as masses cast off from the primitive yelk, and thus differentiated to form an organ concerned in the production of the chitinous envelope of the egg. Then, again, Leuckart speaks of certain "croupy masses" (resulting from the enteritis produced by Trichiniasis) as capable of resolving themselves into psorospermix : and I have myself witnessed what I presumed to be the actual conversion of the granular and molecular contents of the eggs of Fasciola hepatica into amreboids. Leuckart, however, from prior and independent observation, had considered these bodies to be the parasitic confervoid zoospores of Chytridizm.

Undoubtedly, appearances of this varied description are very puzzling; not so much, however, in the view of determining their actual character and nature as for the correct interpretation of their true mode of origination. Perhaps, if one were not, in a measure, dominated by the preconceived idea that these last-named bodies must have sprung from invisible germs, the apparent ocular evidence to the contrary would at once be held as a sufficient explanation. Be this as it may, I may refer in this connection to some interesting facts which have recently been recorded by Profs. F. Sommer and L. Landois, To their interesting "Beiträge zur Anatomie der Plattwürmer" I shall again have occasion to allude for other purposes, but for the present I merely quote the following short passage. Speaking of structures observed in the segments or proglottides of Bothriocephalus latus, they say $(\mathrm{p} .16):-$

"On a level with the folds of the seminal ducts, either close to or lying between them, we observed in the majority of instances within the sexually mature segments round or oval hollow spaces from 0.055 to $0.288 \mathrm{~m}$. in diameter.* Their margins were sharply defined, most of them being filled with a finely granular molecular mass; in others the contents appeared coarsely granular, highly refracting. In an especial manner carmine tinctured the finely granular contents vividly red, whilst the coarse granules effected the reduction of osmic acid (Ueberosmiumsäure) in a very marked degree; on the other hand the reduction by the fine granules was less marked. Further research showed that these granules consisted of very minute fat particles which, since they were little affected by the direct application of ether, appear to possess an albumenoid covering capable of being slightly tinctured by carmine. We did not observe any of these formations in immature joints; their number also varied much in the ripe segments; of such we counted from one

$$
\text { * About } \frac{1}{6} \frac{1}{6}{ }^{\prime \prime} \text { to } \frac{1}{20} 0^{\prime \prime} \text { Eng. measurement.-T. S. C. }
$$

to six in a joint ; other sexually mature proglottides being altogether free. They appeared especially in the neighbourhood of the lower end of the seminal duct in front and behind, where the seminal passage approaches the cistern-like seminal reservoir. We regard these formations as detached portions of the seminal canal, namely, of the larger ducts, whose contents are in a state of fatty degeneration."

Such are the facts. Are the bodies in question really pathological products, or are they not, rather, superfluous developments? It cannot be said they are necessary constituents of the parasite; and it will, perhaps, be denied that they are in any sense heterogenetically formed organisms. At all events, these cast-off bodies have a gregariniform look about them, judging from the representations given by Drs. Sommer and Landois. The expression " hollow spaces" (Hohlraïme) is certainly rather misleading; the more so since they are rendered somewhat opaque by the crowding of their granular contents

If it be true, as some teach, that protoplasms only beget their own kinds of protoplasm, one is at a loss to understand many of the ordinary phenomena of metamorphosis. for myself, I look upon certain of these obscure developments as the result of a law of what I term "vegetative deterioration." Under ordinary circumstances (as for example in the case of the "innovations" produced from abortive prothallia in Ferns) the law of Pangenesis ensures a repetition of parts in all respects similar to those whence the buddings have arisen; but surely it is not necessary to regard all anomalous and detached structures either as morbid products on the one hand, or as germ-begotten entities ion the other. Without letting the imagination run wild, it appears to me perfectly conceivable that "bodies" of a kind more organised than Drs. Sommers" and Landois' "formations," may result from the operation of this law of degradational metamorphosis or "vegetative deterioration."

T. SPENCER COBBOLD

\section{DR. LIVINGSTONE'S DISCOVERIES}

FROM Mr. Stanley's despatches to the New York Herald, which, by the courtesy of the English representative of that paper, have appeared in the Times, we gather some important and definite information as to the exact nature of Livingstone's discoveries ; and more than this, we have a full explanation of the circumstances which kept our great traveller so long out of the reach of civilisation, and of the work he still hopes to accomplish

Mr. Stanley's account of his meeting with Livingstone is a touching one. After many delays, on the 3 rd of November, I87 I, he came in sight of the outlying houses of Ujiji, and, anxious to enter the African town with as much éclat as possible, he disposed his little band in such a manner as to form a somewhat imposing procession. At the head was borne the American flag; next came the armed escort, who were directed to discharge their firearms with as much rapidity as possible; following these were the baggage men, the horses, and asses; and in the rear of all came Mr. Stanley himself. The din of the firing aroused the inhabitants of Ujiji to the fact that strangers were approaching, and they flocked out in great crowds, filling the air with deafening shouts, and beating violently on their rude musical instruments.

As the procession entered the town Mr. Stanley observed a group of Arabs on the right, in the centre of whom was a pale-looking, grey-bearded, white man, whose fair skin contrasted with the sunburnt visages of those by whom he was surrounded. Passing from the rear of the procession to the front, the American traveller noticed the white man was clad in a red woollen jacket, and wore upon his 
head a naval cap with a faded gilt band round it. In an instant he recognised the Eu pean as none other than Dr. Livingstone himself; and he was about to rush forward and embrace him, when the thought occurred he was in the presence of Arabs, who, being accustomed to conceal their feelings, were very likely to found their estimate of a man upon the manner in which he conceals his own. A dignified Arab chieftain, moreover, stood by, and this confirmed Mr. Stanley in his resolution to show no symptoms of rejoicing or excitement. Slowly advancing towards the great traveller, he bowed and said, "Dr. Livingstone, I presume?" to which address the latter, who was fully equal to the occasion, simply smiled and replied "Yes." It was not till some hours afterwards, when alone together, seated on a goat skin, that the two white men exchanged those congratulations which both were eager to express, and recounted their respective difficulties and adventures.

Mr. Stanley's statement is that Dr. Livingstone appeared to be in remarkably good health, stout and strong, quite undismayed by all that he had gone through, and eager only to finish the task he had imposed upon himself.

Dr. Livingstone's story of his adventure was to the following effect:-In March 1866, he started from Zanzibar. The expedition which he led consisted of twelve Sepoys, nine Johanna men, seven liberated slaves, and two Zambesi men-in all thirty persons. At first Dr. Livingstone travelled along the left bank of the Rovuma River; but, as he pursued his way, his men began to grow disaffected and frightened, and, in spite of all his efforts to manage and keep them together, most of them left him and returned to their homes, spreading everywhere the report of his death as a reason for their reappearance there. In August 1866 , he arrived in the terititory of Mponda, a chief who rules over a tribe living near the N'yassa Lake; and here Wikoteni, a protége of the Doctor's, insisted upon being absolved from going any further. After resting for a short time in Mponda's ground, Dr. Livingstone proceeded to inspect the "heel" of the N'yassa Lake ; and it was while carrying out this enterprise that the Johanna men, who had till now remained faithful, deserted him. In December 1866 , having collected a number of natives, Dr. Livingstone decided upon advancing in a northerly direction; and, in pursuance of this determination, he traversed the countries of Babisa, Bobembene, and Borunga, as well as the region of Londa.

Approaching King Cazembe's territory, he crossed a thin stream called the Chambezi ; and here he found himself in great difficulty, being for a long while unable to discover to what the river belonged. The confusion which he experienced was greatly increased by the fact that Portuguese travellers had previously reported the existence of such a stream, and had asserted that it was a tributary of the great Zambesi river, having no connection whatever with the Nile. These statements Dr. Livingstone was disinclined to believe, and, determined to satisfy himself as to the rise and falling of the Chambezi, he made up his mind to devote himself to the task at once. From the beginning of 1867 to the middle of March 1869 , he traversed the banks of the mysterious stream, tracing it where it ran, correcting the errors of the Portuguese travellers, and proving conclusively that the Chambezi was not the head of the Zambezi river, as had been hitherto supposed. So constantly did he remain at this work, and so frequent were the inquiries which he made in every direction, that the natives, in astonishment at his persistence, supposed him to be insane ; and their frequent remark was, "The man is mad; he must have water on the brain." Their ridicule had, however, no effect upon him, for he continued his work in spite of every opposition, and as the result of his labours in this region, coupled with his further researches, he has established conclusively (I) that the Portuguese Zambezi and the Chambezi are totally distinct streams; and (2) that the
Chambezi is the head waters of the Nile. He found that starting from $1 I^{\circ}$ south, the River Nile rolled on until it attained the extraordinary length of 2,600 miles.

In the midst of his wanderings Livingstone came upon Lake Liemba, which he discovered to bs fed by Lake Tanganyika. His map of the last-mentioned lake shows that the southern portion of it resembles in shape the lower part of the kingdom of Italy. He found that it rises in $8^{\circ} 42^{\prime \prime}$ south, is 325 miles in length, being thus seventy-three miles longer than was supposed by Captain Burton and Captain Speke. Leaving Tanganyika, the Doctor crossed Marungua, and came in sight of a small lake, called Lake Muero, which he found to be six miles in length, and to be fed by the Chambezi. In his way he traced the Chambezi running through three degrees of latitide, and having thus satisfied himself of the total independence of the Zambezi, he returned to King Cazembe's country, and then made his way to Ujiji, where, early in 1869 , he wrote letters and despatched them by messengers. A short rest was made at Ujiji, and having explored the head of the Tanganyika lake, and thus finding out that the River Rusizi flowed into the lake, and not out of it, as had been supposed, he made preparations for another, and as he then hoped, a final journey of exploration.

Leaving Ujiji in June 1869 , he pushed through the Uguhba country, and after fifteen days' march he came to Mamgema, which he found to be a virgin country, the interior of which seemed utterly unknown to anybody. As he was about to proceed, however, he was seized with an illness which at one time almost threatened to put an end to his explorations. Ulcers formed in his feet, and for six weary months he was obliged to rest and wait. As soon as he had recovered he started off in a northerly direction, and came shortly afterwards to a broad river called Lualaba, which flowed in a northerly, westerly, and southerly direction. Strongly suspecting that this river was but a continuation of the Chambezi, which enters the Banguereolo, Luapula, and Muero lakes, he retraced his steps to Lake Kamolondo, and thence working his way to lat. $4^{\circ}$ south, and after a long and difficult journey, he found the point where the Lualaba and Chambezi joined, and proved them to be both one and the same river.

He followed the course of the latter river for several hundred miles, and had come within 180 miles of that part of the Nile which has already been traced, when the men he had with him mutinied, and deserted him. Having now neither stores nor followers, he was ob!iged to retire to Ujiji, weary and destitute. It was soon after this that Mr. Stanley found him. In fact, the English explorer arrived at Ujiji on the 16 th of October, I871, and it was, as already stated, no later than the 3 rd of November when the American searcher made his entrance into Ujiji.

On Nov. 20 Dr. Livingstone and Mr. Stanley ieft Ujiji in company, and explored the northern end of Lake Tanganyika, confirming by a second inspection the observations which Dr. Livingstone had previously made; and after 28 days thus pleasantly spent, they returned to Ujiji, and there passed Christmas Day together. On Dec. 26 they left for Unyanyembe, and, arriving there, stayed together till March I4, when Mr. Stanley, intrusted with letters from $\mathrm{Dr}$. Livingstone, started for the coast, leaving the explorer to continue his searches for some time longer.

Dr. Livingstone states that he considers he has yet two problems to solve in connection with the Nile. The first, the complete exploration of the remaining 180 miles which lie between the spot where he was compelled to turn back and the part already traced; and he should investigate the truth of a report which has several times reached him respecting four fountains, which he has been told, supply a large volume of water to the Lualaba. To complete this task, Livingstone estimates that he will require sixteen or eighteen months. Mr. Stanley, however, is of opinion that it will occupy a longer perizd. 